\title{
MICROBIOLOGICAL AIR RATING IN A VARIETY OF OBJECTS DURING TREATMENT OF THE POST-SLAUGHTER POULTRY WASTES PART I. ESCHERICHIA COLI
}

\author{
Sanaa Mahdi Oraibi ${ }^{1}, K^{\prime}$ rystyna Cybulska ${ }^{1}$ \\ 1 Department of Microbiology and Environmental Biotechnology, West Pomeranian University of Technology \\ in Szczecin, Słowackiego 17 Str., 71-434 Szczecin, Poland, e-mail: krystyna.cybulska@zut.edu.pl
}

Received: 2016.08.11 Accepted: 2016.09.26 Published: 2016.11.01

\begin{abstract}
The presence of Escherichia coli in the air of facilities involved in management and composting of post-slaughter poultry wastes in selected plants of West Western Pomerania region was studied. Measurements were made on four dates in a variety of weather conditions during the year. The study was conducted at 5 objects that differ in the type of waste and the degree of preparation for composting. These were: chemical treatment and preliminary processing plant, liquid wastes reservoir, platform for preparation of materials for composting, storage of biological sediments, and composting facility. Measurement of bacteria count was carried out in accordance with the applicable procedures on selective chromogenic TBX medium. The assays revealed the presence of $E$. coli at all test objects, but not always on all measurement dates. It has been shown that the presence of $E$. coli was from 20 to $3047 \mathrm{CFU} \cdot \mathrm{m}^{-3}$ of air, although the largest quantities were most frequently detected in the air of the building for post-slaughter waste pre-treatment in chemical treatment plant.
\end{abstract}

Keywords: E. coli, air, poultry waste facilities, composting

\section{INTRODUCTION}

Poultry farms are associated with high production of dust, gases and odors. The aerosol floats bacteria freely in the air and they may also be attached to different particles (Whyte, 1993). Concentration and type of microorganisms in the air depends on various factors such as type of buildings system, number of animals, type of ventilation systems, and microclimate conditions (temperature, humidity, gas concentration, light, or dust concentration) (Green et al., 2009).

The air pollutants, that are generated during animal and poultry breeding, adversely affect the sense and health of employees and stuff (Donham et al.,1989, Dungan, 2010). Microorganisms can also be transmitted from this type of objects over long distances and affect the residents of nearby habitats (Cox \& Wathes, 1995, Radon, 2007, Ritz et al., 2006, Stetzenbach et al., 2004). In a poul- try industry, the following pathogenic species are most often met: Campylobacter spp., E. coli, Staphylococcus spp., Salmonella spp., Clostridium perfringens and Enterococcus faecalis ( Mc Dermott et al., 2005; Gyles, 2008; Chinivasagam et al., 2009; Brooks et al., 2010; Just et al., 2011).

Escherichia coli is a gram-negative bacteria, motile, facultative anaerobic, classified into the family of Enterobacteriaceae (Buxton and Fraser, 1977). In poultry breeding, this bacterium most commonly causes infections and diseases, and from $5 \%$ to $50 \%$ of cases are fatal (Gomes et al., 2005). Genetically, E. coli is the most versatile bacteria, which is a source of numerous plasmids (Saylers and Whitt, 2002).

The aim of our study was rating the composition of bioaerosol in terms of $E$. coli presence from March 2015 until January 2016 in the composting facility on a selected example of poultry processing enterprise in Western Pomerania region. 


\section{MATERIAL AND METHODS}

The air samples were collected at five measurement points with different characteristics (different locations):

1. Reservoirs for liquid wastes,

2. Preparation of wastes after processing for composting,

3. Storage of sediments from biological treatment plant,

4. Composting facility,

5. Building for pre-treatment with chemical processing.

Air samples were collected at 4 dates under weather conditions presented in Table 1. Analyzed objects such as buildings, composting facility, other devices for management and processing of waste into the compost were fenced depending on the stage of processing the material - with concrete fence of height from 2 to $5 \mathrm{~m}$.

The sedimentation method was used in our study and the count of microorganisms was expressed as the number of cells able to develop per $1 \mathrm{~m}^{3} \mathrm{CFU} \cdot \mathrm{m}^{-3}$ [PN-89/Z-04111/01; PN89/Z-04111/02]. To determine the number of $E$. coli count, selective chromogenic differentiating TBX medium was applied. Exposure of Petri dishes for air sampling was opened for 15 minutes. Incubation of microorganisms was carried out in incubators at $44{ }^{\circ} \mathrm{C}$ for $24 \mathrm{~h}$ [Delisle and Ley; 1989]. Characteristic blue colonies were counted (Photo 1) and expressed in Colony Forming Units per $\mathrm{m}^{3}$ of air and then the results were analyzed using Statistica 12 software.

\section{RESULTS AND DISCUSSION}

In our study in depending on the objects and time sampling highly variable of the number of $E$. coli was observed (Figure 1). Air pollution with E. coli occurred in $65 \%$ of measurements. Statistical analysis confirmed the presence of highly significant effect of the sampling object, date and interaction of both factors on the bacteria count. The concentration and type of microorganisms in the air depends on various factors such as the type of buildings system, number of animals, type of ventilation system, and other conditions including temperature, humidity, gas concentrations, light, or dust concentration (Green et al., 2009). Air pollution, including biological one, which is generated during the breeding of livestock and poultry, like in the case of these analyzed objects, can have a significant impact on the increase of this type of pollution and health effects on workers and service stuff (Donham et al.,1989, Dungan, 2010).

$E$. coli bacteria were found in the air above the landfill of wastes prepared for composting (location 2) once, but only on the second date of measurement. The air pollution occurred twice in the air above the liquid waste reservoir (location 1), three times in the air above the landfill of wastes from the centrifuge and composting facility (location 3 and 4). In all measurement dates, E. coli bacteria were present in the air of the building of the post-slaughter waste pre-treatment in chemical treatment plant (location 5).

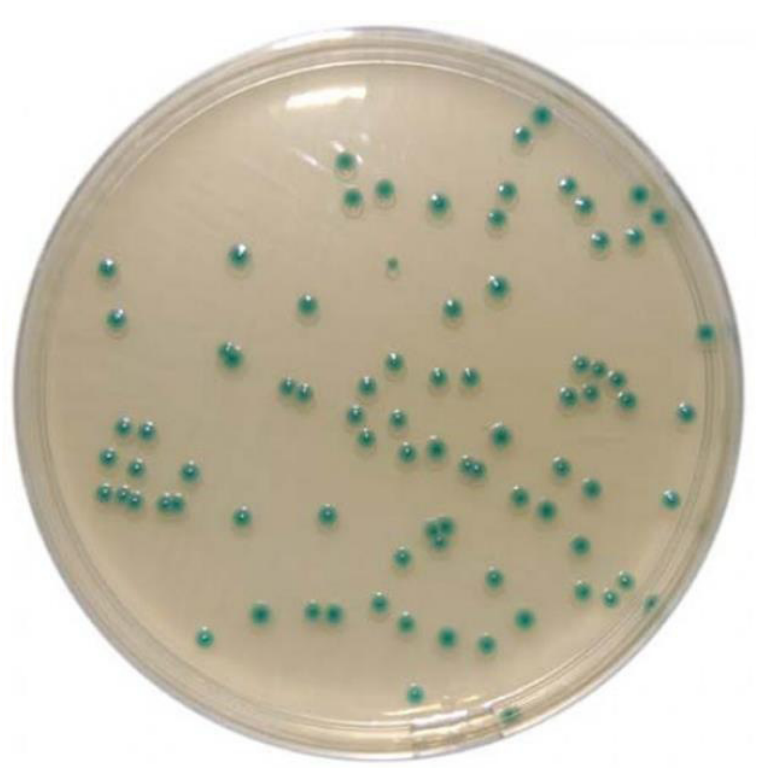

Photo 1. Colonies of E. coli on TBX medium

Table 1. Weather conditions during sampling of bacteria sedimentation from the air of composting facility and building for poultry wastes management

\begin{tabular}{|c|c|c|c|c|}
\hline \multirow{2}{*}{ Parametr } & \multicolumn{4}{|c|}{ Date } \\
\cline { 2 - 5 } & I & II & III & IV \\
\cline { 2 - 5 } & $19.03 .2015 \mathrm{yr}$ & $21.05 .2015 \mathrm{yr}$ & $25.06 .2015 \mathrm{yr}$ & $14.01 .2016 \mathrm{yr}$ \\
\hline Temperature $\left[{ }^{\circ} \mathrm{C}\right]$ & 6 & 13 & 17 & 1 \\
\hline Relative humidity $[\%]$ & 49 & 61 & 72 & 92 \\
\hline Wind speed $[\mathrm{m} / \mathrm{s}]$ & 1 & 1 & 2 & 1 \\
\hline
\end{tabular}


Location 1

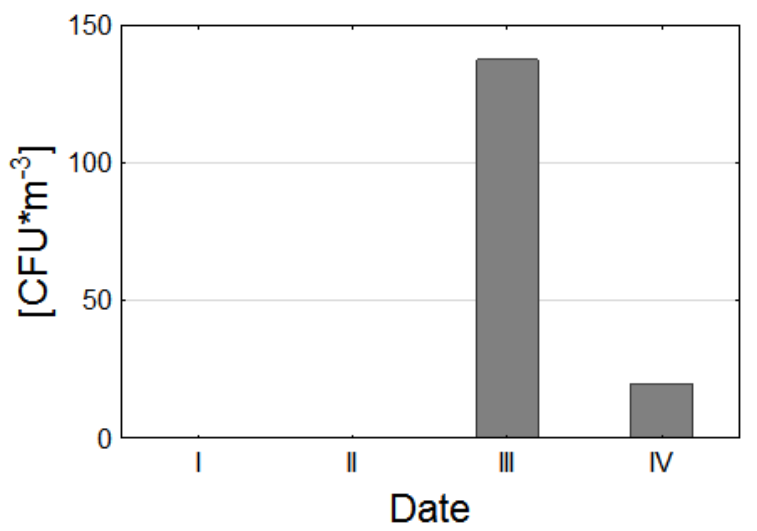

Location 3

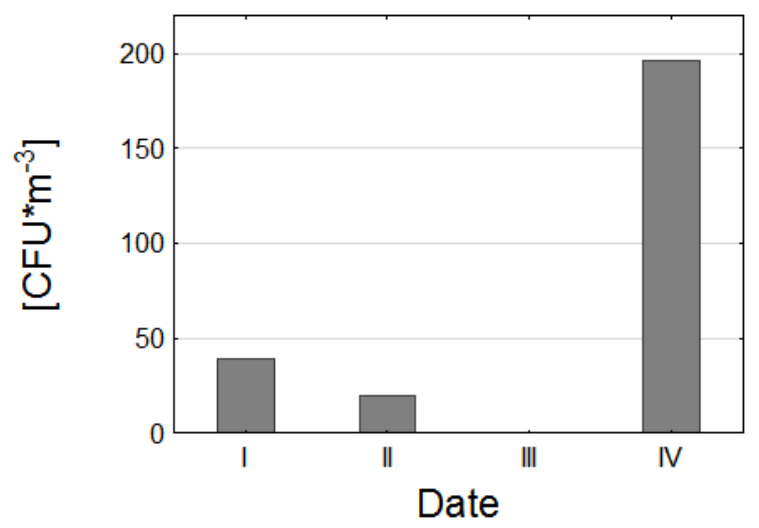

Location 2

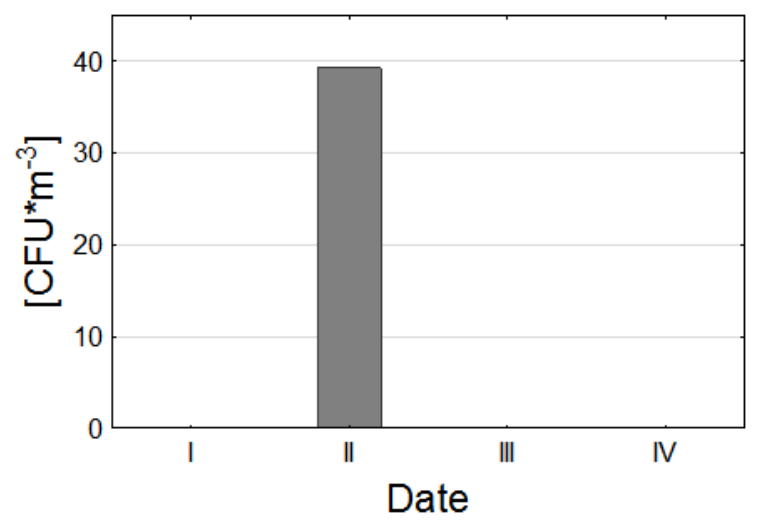

Location 4

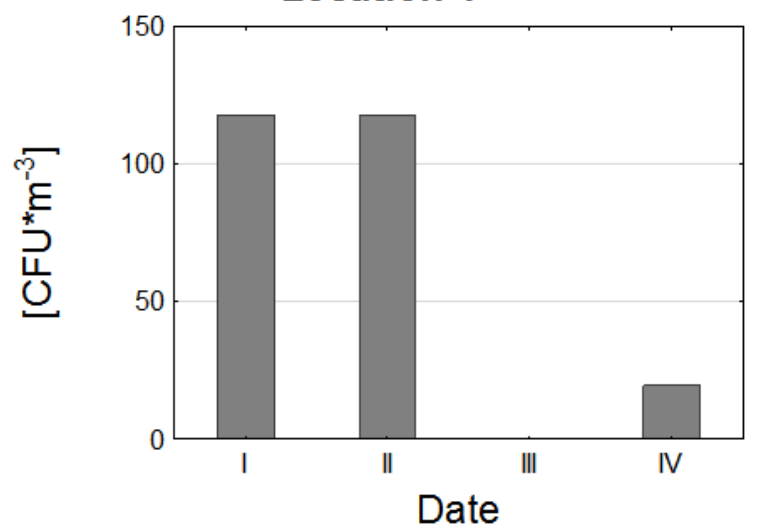

Location 5

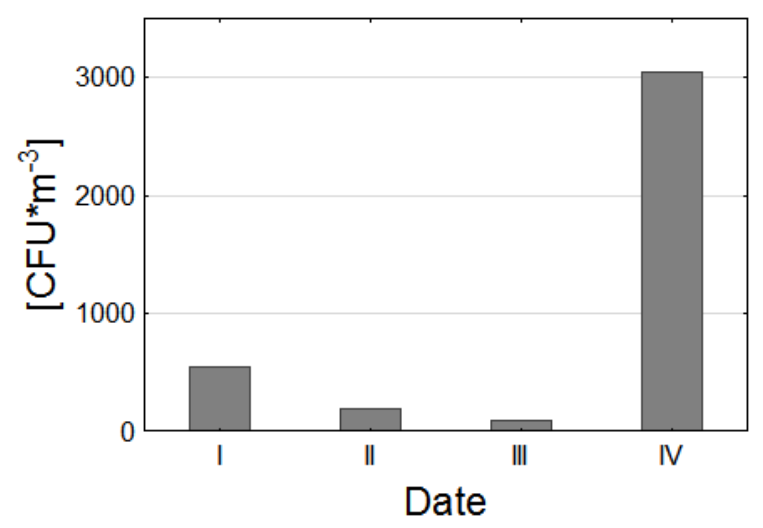

Figure 1. Number of E. coli $\left[\mathrm{CFU} \cdot \mathrm{m}^{-3}\right]$ in tested locations on particular measurement dates

The number of Escherichia coli in the air was characterized by a similar spread of the bacteria occurrence for the first four measurement points. The last measurement point (location 5) considerably differed from other ones in this respect. Microorganisms, including E. coli, can be transferred over long distances (Cox \& Wathes, 1995, Radon, 2007, Ritz et al., 2006, Stetzenbach et al., 2004). It is important that such objects were specially secured and fenced with screens preventing the entry of contaminated air to the surrounding areas. Poultry farms are particularly associated with high production of dusts, gases and odors, and bacteria float and spread within the environment (Whyte, 1993). 
Count of E. coli bacteria in analyzed air was from 20 to $3047 \mathrm{CFU} \cdot \mathrm{m}^{-3}$. For individual measurement points, the average values remarkably differed. The lowest mean air pollution (almost 10 $\mathrm{CFU} \cdot \mathrm{m}^{-3}$ ) was observed over the landfill of wastes prepared for composting (location 2). Then in increasing sequence: air at the liquid waste reservoir $-40 \mathrm{CFU} \cdot \mathrm{m}^{-3}$ (location 1), landfill of wastes from centrifuge and composting facility $-64 \mathrm{CFU} \cdot \mathrm{m}^{-3}$ (locations 3 and 4), and the largest - in the air of the pre-treatment of poultry wastes in chemical treatment plant building - $973 \mathrm{CFU} \cdot \mathrm{m}^{-3}$ (location 5). Performed cluster analysis shows that among the studied measurement points, location 5 (chemical treatment plant) was a separate group of air pollution with E. coli bacteria. The second one includes all other locations, that are closely related to each other, including locations 2 and 4 (landfill of wastes prepared for composting) form a group with a similar level of contamination with E. coli bacteria.

It is extremely important to monitor the spread of $E$. coli bacteria due to a number of diseases that can be caused both to animals and humans and also because of the increasing effect of bacteria immunization (Riley et al., 1983; Chansiripornchai 2009; Ferens and Hovde 2011).

\section{CONCLUSIONS}

1. Air pollution with E. coli in analyzed area of the post-slaughter poultry waste management occurred in about $65 \%$ of the observations. Bacteria was detected at all measurement points and dates, and the resulting numbers

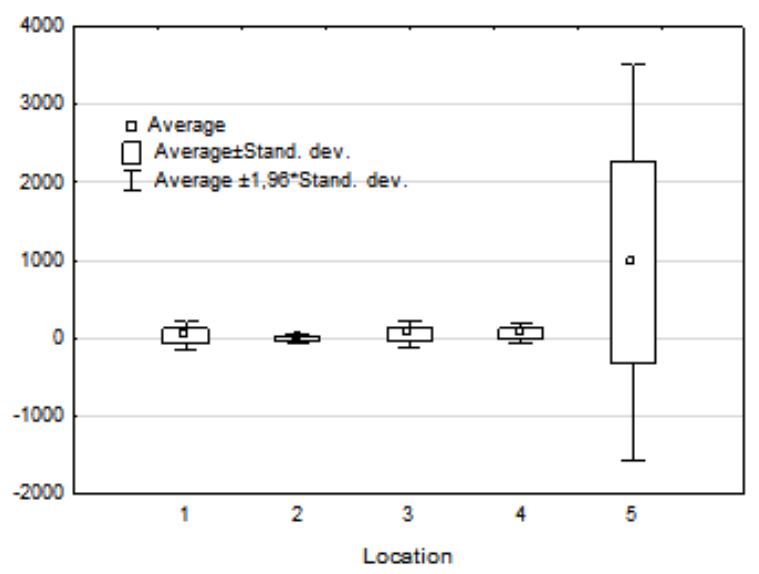

Figure 2. Characteristics of Escherichia coli number distribution in the air of studied measurement points showed essential differences. At measuring points 1 through 4 on certain dates, presence of the bacteria in the air was not detected. Only in the air of chemical treatment plant and pretreatment of waste building, they were always detectable, although in substantially varying quantities.

2. The pollution due to E. coli bacteria was from 20 to $3047 \mathrm{CFU} \cdot \mathrm{m}^{-3}$ of air. Tested locations can be lined up according to the increasing pollution: landfill of wastes prepared for composting (location 2), liquid wastes reservoir (location 1), landfill of wastes from centrifuge and composting facility (locations 3 and 4), as well as a separate group with the largest pollution formed by chemical treatment plant along with waste pre-treatment plant (location 5).

\section{REFERENCES}

1. Brooks J.P., McLaughlin M.R., Scheffler B., Miles D.M. 2010. Microbial and antibiotic resistant constituents associated with biological aerosols and poultry litter within a commercial poultry house. Sci Total Environ. 408, 4770-7. DOI:10.1016/j. scitotenv.2010.06.038.

2. Buxton A., Fraser G. 1977. Escherichia coli. In Animal Microbiology Blackwell Scientific Publications. Oxford, London, Edinburg, Melbourne. 1, 78-80.

3. Chansiripornchai N. 2009. Comparative efficacy of enrofloxacin and oxytetracycline by different administration methods in broilers after experimental infection with avian pathogenic Escherichia coli. Thai J Vet Med. 39, 231-236.

4. Chinivasagam H.N., Tran T., Maddock L., Gale A., Blackall P.J. 2009. Mechanically ventilated broiler sheds: a possible source of aerosolized Salmonella, Campylobacter, and Escherichia coli. Appl Environ Microbiol. 75, 7417-25. DOI:10.1111 /j.1365-2672.2009.04571.

5. Cox C.S., Wathes C.M. 1995. Bioaerosols in the environment. In Bioaerosols Handbook. Boca Raton, FL: Lewis Publishers; Edited by CS Cox and CM Wathes. 11-14.

6. Delisle G., Ley A. 1989. Rapid detection of E.coli in urine samples by a new chromogenic ß-glucuronidase assay. J. Clin.Microbiol. 27, 778-779.

7. Donham K.; Haglind P.; Peterson Y.; Rylander R.; Belin L. 1989. Environmental and Health Studies of Farm Workers in Swedish Swine Confinement Buildings. Br. J. Ind. Med. 46, 31-37.

8. Dungan, R.S. 2010. Board-invited review: Fate and Transport of Bioaerosols Associated with 
Livestock Operations and Manures. J. Anim. Sci. 88, 3693-3706. DOI: 10.2527/jas.2010-3094.

9. Ferens W., Hovde C. (2011): Escherichia coli O157:H7: animal reservoir and sources of human infection. Foodborne Pathogens and Disease 8,465-485. DOI: $10.1089 /$ fpd.2010.0673

10. Gomes A.R., Muniyappa L., Krishnappa G., Suryanarayana V.V.S., Isloor S., Prakash B., Hugar P.G. 2005. Genotypic Characterization of Avian Escherichia coli by Random Amplification of Polymorphic DNA. Int. J. Poult. Sci. 4, 378-381. DOI:10.3923/ijps.2005.378.381.

11. Green A.R., Wesley I., Trampel D.W., Xin H. 2009. Air quality and bird health status in three types of commercial egg layer houses. J Appl Poultry Res. 18(3), 605-621. DOI: 10.3382/japr.2007-00086.

12. Gyles C.L. 2008 Antimicrobial resistance in selected bacteriafrom poultry. Anim Health Res Rev. 9, 149-58. DOI:org/10.1017/s1466252308001552.

13. Just N., Kirychuk S., Gilbert Y., Létourneau V., Veillette M., Singh B., Duchaine C. 2011. Bacterial diversity characterization of bioaerosols from cage-housed and floorhoused poultry operations. Environ Res. 111, 492-8. DOI:10.1016/j.envres.2011.01.009.

14. McDermott P.F., Cullen P., Hubert S.K., McDermott S.D., Bartholomew M., Simjee S., Wagner D.D. 2005. Changes in antimicrobial susceptibility of native Enterococcus faecium in chickens fed virginiamycin. Appl Environ Microbiol. 71(9), 49864991. DOI:10.1128/AEM.71.9.4986-4991.2005.

15. PN-89/Z-04111/01. Ochrona czystości powietrza. Badania mikrobiologiczne. Postanowienia ogólne i zakres normy. PKNMiJ, Wydawnictwo Normalizacyjne "Alfa" 1989r.
16. PN-89/Z-04111/02 - Ochrona czystości powietrza. Badania mikrobiologiczne. Oznaczenie liczby bakterii w powietrzu atmosferycznym (imisja) przy pobieraniu próbek metodą aspirometryczna i sedymentacyjną. PKNMiJ, Wydawnictwo Normalizacyjne "Alfa"1989r.

17. Radon K., Schulze A., Ehrenstein V., van Strien RT., Praml G., Nowak D. 2007. Environmental exposure to confined animal feeding operations and respiratory health of neighboring residents. Epidemiol. 18, 300-308. DOI: 10.1097/01. ede.0000259966.62137.84.

18. Riley L.W., Remis R.S., Helgerson S.D, Mcgee H.B., Wells J.G., Davis B.R., Hebert R.J., Olcott E.S., Johnson L.M., Hargrett N.T., Blake P.A., Cohen M.L. 1983. Hemorrhagic colitis associated with a rare Escherichia coli serotype. N Engl J Med. 308(12), 681-685.

19. Ritz C.W., Mitchell B.W., Fairchild B.D., Czarick III M., Worley J.W. 2006. Improving in-house air quality in broiler production facilities using an electrostatic spacecharge system. J Appl Poult Res. 15, 333-340. DOI:/10.1093/japr/15.2.333.

20. Saylers A.A., Whitt D.D. 2002. Diarrhoeagenic Escherichia coli strains. In: Bacterial Pathogenesis, A. Molecular Approach. 2nd edition. ASM Press. American Society for Microbiology. USA. 28, 407-420.

21. Stetzenbach L.D., Buttner M.P., Cruz P. 2004. Detection and enumeration of airborne contaminants. Curr Biotechnol. 15, 170-4. DOI:10.1016/j.copbio.2004.04.009

22. Whyte R.T. 1993. Aerial pollutants and the health of poultry farmers. Worlds Poult Sci J. 49, 139-53. 